\title{
Portrait of LGBT In Modern Indonesia Novels
}

\author{
Yasnur Asri, Yenni Hayati \\ Universitas Negeri Padang \\ yasnurasri5@gmail.com
}

\begin{abstract}
This study aimed to; (1) describe and analyze the phenomena of LGBT in Modern Indonesian's Novel, (2) analyze whether the emergence of LGBT phenomena in Indonesian's novels have its correlations with the existence of $L G B T$ in real situation, (3) investigate the relation of the LGBT phenomena in novels with the view of feminism that thrives in the minds and cultures of Indonesia. The method used in this study was descriptive qualitative; since the purpose of this study was to depict thoroughly the views of women literature. Based on the data analysis, the results were: First. there are six form of sexual intercourse which represented in modern Indonesia's novel, they are; (1) sexual intercourse between females (lesbian); (2) sexual intercourse between males (gay); (3) Sexual Intercourse outside of marriage and whoring; (4) Affair relationship (5) sexual intercourse between husband and wife (normal law); and (6) Incest. Second, the portrait of LGBT behavior in modern Indonesia's novels which only consists of three, they are; (a) Lesbian found in Garis Tepian Seorang Lesbian, Larung, and Nayla. (b) gay in Supernova, Mahadewa-mahadewi and Dadaisme and mix intercourse of lesbian and gay in Tabularasa. Special for the sexual intercourse between women, it is done by the characters of the novel as form of protests to the practice patriarchy which is based ideology of radical feminism. Third, the phenomena of LGBT represented in modern Indonesia's novels have relevance with society sociocultural.
\end{abstract}

Keywords-- behavior portrait, LGBT, homosexual, contemporary novel

\section{INTRODUCTION}

There are some ideologies behind the foundation of why it is important to investigate LGBT phenomena in modern Indonesia's novel. First, the issue regarding lesbian, gay, bisexual and transgender (LGBT) -particularly lesbian and gay - lately have become a trending issue among the people of Indonesia. This not only can be found in promotional and advertisements of LGBT in social media, but also can be found in the middle of society. It is proven by some countries that have legalized a constitution regarding the issue of LGBT. Oetomo (2003, p. 19) claims that the first country to ever legalized same sex marriage is Denmark on October 1, 1989. This becomes historical day for the lesbian and gay in the whole world. Some results of survey from domestic and foreign independent institution said that Indonesia caught wind of the issue of LGBT. The result of survey stated that there are 3\% LGBT from total population. It means there are 7.5 million of 250 million people of Indonesia that have something to do with LGBT behavior, especially lesbian and gay. The LGBT issue becomes viral after the legalization of same-sex marriage in Denmark on October 1 1989. Oetomo (2003, p. 129) explains that October 11989 is a historical date for lesbian and gay in the whole world because on that day for the first time they were accepted by the legal marriage law devised by Denmark. After that, there are many other countries that follow Denmark, legalize same-sex marriage.

Facing this reality, pro and contra emerged in Indonesia society. To those who are pro to the existence of LGBT, says that a country and its people must not discriminate between opposite-sex couples (heterosexual) and samesex couples (homosexual) because such is human rights. On the contrary, those who are contra to the existence of LGBT, thought LGBT as an irregularity and is not included in conceptualization of HAM (Human Rights). Therefore, the country have obligations to prevent such thing to save future generations. Other than that, the contras make arguments from the perspective of religion. From the perspective of religion (Islam) homosexual and heterosexual are considered to be great sin, because it is not in accordance with norm of religion, norm ethics and sunattullah (natural law).

Second, LGBT phenomena are not only found in the objective reality (society), but also can be found in imaginative reality (literary works). Based on results of reading some of modern Indonesia's novels, it is found that some modern novel in Indonesia take the issue of LGBT. Those novels are; Larung written by Ayu Utami. Garis Tepi Seorang Lesbian written by Herlinatiens, Supernova written by Dewi Lestari, Mahadewa-mahadewi written by Nova Riyanti Yusuf, Tabularasa written by Ratih Kumala, Dadaisme written by Dewi Lestari, Nayla written by Djaenar Maesa Ayu and others. What more interesting is, that all of these novels are written by females writers. It turns out that those female writers are freer and braver to pick LGBT problems in their novel rather than male writers. They are brave enough to fight the taboo that becomes a buried magma within society with cultural conventions. Their works with the color of sex are interesting because they violate the behavioral norm of traditional society, thus through resistance towards this taboo, they rip off the disguised taboo towards women, especially regarding LGBT. The existence of their works, considered to be an oases to the people who are heated" by the eastern ethics which are not brave enough to 
fight it up front. What becomes problem is that. Is there correlation between the women literati bravery in taking LGBT issue in their works with the cultural trend that alive within the society of Indonesian people?

Third, LGBT in this study can be defined as a primary orientation or choice of sex or as a basic to someone, which implemented through the same gender. This behavior can happen in the form of lesbian or gay. These two sex behavior are often called by the terms of homosexual and heterosexual. According to Oetomo (2003, p. 6) homosexual is a term that refers to a psycho-sexual phenomena in clinical connotation. Then, homosexual is differentiated into two, they are; gay to call homosexual people between men, which their orientations are men to men, and lesbian to call homosexual people between women, which their orientations are women to women along with heterosexual to call those who have these two tendency of sexual behavior. Moreover, Oetomo (2003, p. 28-29) there are two perspective which are usually used in understanding homosexual phenomena; (1) essentialism, tend to understand homosexual as a person's mental state that is given, but society put up resistance to such individual. This perspective is supported by many lesbian and gay activists; and (2) Social-construction, that assume homosexual phenomena as a social construct. This perspective is adopted by many social experts who are affected by Michael Foucault thinking in the 1970s.

Fourth, the intertwining interest between literary works (in this case modern Indonesia's novel) with the objective reality (society) can be explained through theory of sociology of literature. According to Eagleton (2002, p. 20 ) in sociology of literature, literary works is understood in its relation with realty and/or ideology that alive within a society. Sociology of literature always sees literary works as a form of art that is made by literature and has aesthetic value (beauty) in giving entertainment. Other than that, literary works contain many values useful for the good of humanity. In correlation between literary works with its function to the good of humanity in reality, it can be said that all literary works are born from the ideological conception of the world. Moreover, Eagleton (2002, p. 21) explains literature does not mean anything without ideology in a peculiar artistic form or that literature often is just an expression of ideology of its time. To be more extreme, literature even is just a tool to convey a certain ideology, therefore understanding literary work in its essence is the ideology reflected in the literary works. Ideology in this study is a set of values, ideas, norms, beliefs and faiths that is owned by someone or a group of people that becomes the foundation in deciding attitude when facing an event or problem. In accordance with Goldman \& Sheridan (1997, p. 17) in its correlation with literary study, ideology definition is often associated with world view; is a comprehensive complex of arguments, aspirations and feelings which connect members of certain social group altogether and contrast it with other social group. As a world view of a certain social group, thus ideology in society is basically a living superstructure in society which expressed through literary works.

Based on the four rationales above, thus the focus of this study is on the LGBT phenomena represented in modern Indonesia novel. Specifically the focus of this study can be concluded as such:

(1) How is the portrait of sexual intercourse represented in modern Indonesia Novels?

(2) How is the portrait of LGBT behavior represented in modern Indonesia Novels?

(3) How is the relation between LGBT phenomena in modern Indonesia novel with the socio cultural reality of Indonesia society?

\section{METHODS}

This study applied descriptive-qualitative method. In this study, the method tried to specifically depict how women author represent LGBT phenomena in their literary works, their ideology behind that perspective, and the relation to the social reality. To achieve the purpose of this study, content analysis was conducted. This analysis was a research technique to make replicable inferences and valid data by paying attention to the context. The data in this study were words, phrases, and utterances, dialogue of the character or narrator that contains LGBT's actions. The source of the data for this study were series of novel named: Larung (symbolized with L) by Ayu Utami, Garis Tepi Seorang Lesbian (GTSL) by Herlinatiens, Supernova (Sn) by Dewi Lestari, Mahadewa - Mahadewi (MM) by Nova Riyanti Yusuf, Tabularasa (Tr) by Ratih Kumala, Dadaisme (D) by Dewi Lestari, and Nayla (N) by Djenar Maesa Ayu.

\section{Findings}

\section{FINDINGS AND DISCUSSIONS}

Based on the data analysis the findings are as follow. First, seven novels that are being investigated in general talks about portrait of sexual behavior, they are sexual intercourse between women (Lesbian 31 data), sexual intercourse between men (gay 29 data), sexual intercourse not by marriage and whoring (28), affair relationship (20), man and wife sexual intercourse (legal norms 3 data) 1 and sexual intercourse between siblings (incest 1 data) as seen on the following chart.

From the six kind of sexual intercourse what are being discussed only sexual behaviors related to LGBT only, lesbian and gay. However, the other four kind of sexual behaviors are not discussed because this study only focuses on same-sex behavior.

Second, portrait of behavior which represented in the modern Indonesia novels are proposed by women literati. The portrait of sexual behavior proposed are related to three phenomena, they are: (1) phenomena of sexual intercourse 
between women (lesbian) found in 3 novels, 1, they are novel GTS, L and N (2) phenomena of sexual intercourse between men (Gay) found in 3 novel, they are novel Sn, MM and D, and (3) phenomena of mix sexual intercourse between lesbian and Gay phenomena found in novel Tr. For a clearer explanation it can be seen on the following table.

Based on the data above, a finding can be concluded that from the seven novel being investigated, there three novels that makes lesbian as its central issue, they are novel Larung (L) by Utami, novel Garis Tepi Seorang Lesbian (GTSL) by Helinatiens and Nayla (N) by Djaenar Maesa Ayu. Three novels take up Gay issue, they are novel Mahadewa -Mahadewi by Nova Riyanti Yusuf, Supernova and Dadaisme by Dewi Lestari takes up gay phenomena, but without the basis of ideology, but lean towards problem of heterosexual sexual intercourse. On other novel, that is Tabularasa (Tr) takes up issue of mix sexual intercourse between lesbian and gay.

Third, from seven novels investigated it is found that sexual behavior between women are done by character Paria and Rie in novel GTLS; between character Shakuntala and Ruben in novel Sn; between Raras and Violet in novel $\mathrm{D}$; and between character Jing and Ken in novel D. The same-sex sexual intercourse (lesbian and gay) done by the characters are done consciously even they struggle to maintain their same sex relationship, as seen in the behavior of character Shakuntala and Laila: Juli and Nayla: Dimas and Ruben: Raras and Violet: and behavior of character Jing and Ken. Then the same-sex behavior they have done are because of the patriarchy culture (i.e. sexual abuse) that binds women freedom, as seen in the behavior of character Nayla and Juli and the innate factor experienced by character Shakuntala.

\section{Discussion}

As it has been described above, in novel GTSL, the same-sex behavior between women are done by Asmora Paria with her couple Rie Shiva Ashvagosha. The same-sex behavior between these women are done because Rie is forced to be married with a man chosen by her family, Renne. Since that separation both of them can no longer meet, thus give rise to a very deep suffering from within Paria. Paria suffers even more when her parents forced her to married with Mas Wiryo. In the midst of her frustration and confusion in choosing to stay lesbian or follows her family decision, Paria at one time pretend to have a love relationship with a man, Mahendra. In the end, Paria left Mahendra, that she almost mary, after receiving letter from Rie who is in France and have divorced Renne.

How these two women (Paria and Rie) feel the joy of same-sex sexual intercourse, after that first night, continuing to the next relationship. Even both of them are married in France. The first night of after their marriage are depicted as follows:

Dan, aku pikir kau bisa membayangkan apa yang terjadi antara kami selanjutnya. Kami dua orang perawan bergulat dalam batas yang amat tipis.

Dia mengenakan gaun tidur yang terlalu tipis untuk tidak kuperhatikan.Aku sedang haus pemaknaan. Maka jadilah persenggamaan itu (GTSL, data no.3).

Detik-setik menjadi sangat cepat.Menggapai sesuatu yang tergapai dalam saat.Aku meracau.Pedih dalam damai.Pengingkaran cinta atas namanya. Tuhan sekali ini maajkanlah aku... Sampai aku mengenal Rie Shiva Ashvagosha, saat...Tak tahu bagaimana prosesnya, tiba-tiba aku sudah tenang berada dalam dekapan dadanya.Merasakan getaran hebat. Pertama kali sepanjang hidupku.... Tanpa berkata apa-apa aku sangat percaya akan cintanya. Entah bagaimana, tapi ada semacam pohon, pohon yang menarikku untuk lebih erat memeluk tubuh yang menimbulkan andrenalinku orgasme (GTSL, data no. 9).

After both of them are separated because Rie is forced to marry Renne by her parents. Paria express her longing and lust of sex to Rie as follows:

Kasih, peluklah aku.ljinkanlah aku tersedu di dadamu.Seperti saat lalu.Saat kita menjadi dua perawan cinta.Ranjang tempat kita bersenyawa menjadi dingin, tangan-tangan halusmu lama sudah tak menyentuhnya. Dan aku beku di dalamnya (GTSL, data no. 10).

Dan ku tersenyum meraba, mengenang dulu, waktu lalu.Setidaknya masih sam a seperti sekian tahun yang lalu, saat pertama kali kaau mengecup kening dan merenggut rawan bibirku di ranjang suciku. Senja itu pun,rintih jerit air mata dewa berjatuhan membanjiri serombongan semut yang membabi buta karenanya (GTSL, data no. 12).

Rie, Malam-malam dingin seperti ini akan sangat nikmat bergumul dengan pengadaanmu. Erotika Cupido. Aku mencintaimu (GTSL, data No. 16).

In novel L, the sex scene between women (lesbian) are done by character Shakuntala with Laila. Character Shakuntala have never break out of her deviate tendency of sexual behavior. Since her teens, Shakuntala have already 
shows symptoms of her deviate sexual behavior. When she study sinden from a Pesinden. Shakuntala make intimate intercourse with that woman. After she has done, Shakuntala does not feel guilt at all.

Not only make love with the teacher, pesinden, Shakuntala also make love with Laila, her best friend. That intercourse happens deliberately. Shakuntala make up excuse that Laila must know every nook and cranny of her body before having any intercourse with anyone else. With that excuse, Shakuntala deliberately bind Laila to same-sex intercourse after they have finished practicing tango. Shakuntala also realized and feel that deep within her is a man that can come out at any time unexpected. That manhood is what impulses her to do same-sex relationships.

Aku mengelus di punggung dan mencium di kening.Dan aku tidak pergi.Aku tahu kamu belum pernah mengalami orgasme.Juga ketika bercumbu dengannya.Kini tak kubiarkan kamu menemui lelaki itu sebelum kamu mengetahuinya.Sebelum kamu mengenali tubuhmu sendiri.Setelah ini kamu boleh pergi. (L, data no. 11)

In that novel Laila, who is madly in love with Sihar, is frustrated because her plan to date with Sihar, that she has wait and prepare for a long time with full passion and has failed, because Sigar come to Arnerica followed by her wife.

Aku mengelus di punggung dan mencium di kening.Dan aku tidak pergi.Aku tahu kamu belum pernah mengalami orgasme.Juga ketika bercumbu dengannya.Kini tak kubiarkan kamu menemui lelaki itu sebelum kamu mengetahuinya. Sebelum kamu mengenali tubuhmu sendiri.Setelah ini kamu boleh pergi. (L, data no. 11)

Next, in the novel $\mathrm{N}$ by Djaenar Maesa Ayu, same-sex intercourse behavior (lesbian) is done by Nayla and Juli. For this behavior, they done it consciously. Even Juli wants commitment in her same-sex relationship with Nayla. There is no intention in her heart to change her sexual orientations. Juli accepts her sexual orientation behavior as it is. Ego-centric form of Character Juli is depicted in her struggle to withstand her relationship with character Nayla. Juli deliberately book a room in a prestigious hotel to please Nayla's heart. Juli also have brought a ring as sign of the seriousness to take Nayla to her home. But, her love with Nayla is run aground because Nayla does not want to be bound.

Sirna sudah harapan Juli. Yang ia bayangkan sebelumnya, Nayla akan gembira menginap satu malam di kamar suite yang sudah Juli persiapkan untuknya. Berharap Nayla akan menikmati kemewahan itu ketimbang tidur di kamar kosnya yang kumuh. Mereka akan duduk sambil mereguk anggur merah di tepi jendela sambil memandang kemilau lampulampu mobil dan jalan raya di luar sana. Saling menatap mesra seperti seminggu ini mereka lakukan ketika saling berdekapan di dalam kamar kos Nayla. Mereka bisa saja bercinta untuk pertama kalinya, tanpa ada rasa janggal di hati Juli setiap kali ranjang Nayla berderit memekakkan telinga.Bahkan ketika Juli akhirnya terpaksa mengeluarkan juga cincin yang sudah dipersiapkannya, dan meminta Nayla untuk tinggal bersamanya.Nayla menerima dengan biasa-biasa saja (Nayla, data no. 2).

The behavior of character Nayla is also depicted from her attitude that accepts everything as it is. Her bitter past cause Nayla to fall into the dark of night life. Since she was raped by her mother's close friend, Nayla's life is messed up. Her mother's divorced with her father also causing Nayla to hate men. To her, men are jerks who only wants satisfaction from women. Of that reasons, Nayla choose to love women rather than men.

Saya juga punya pacar.Bukan laki-laki, tapi perempuan. Yang laki-laki cuma untuk hit and run. Mereka benar-benar makhluk yang menyebalkan, sekaligus menggiurkan.Tapi untuk urusan perasaan, saya lebih merasa nyaman dengan perempuan.Entah salah atau benar, saya menemukan Ibu di dalam dirinya.Saya rindu Ibu (Nayla, data no. 1).

Sexual intercourse between men (gay) between Raras and Violet in Tabulasa (Tr) cause a heterosexual love relationship between Galih and Raras end, because Raras hides her love passion with Vi (Violet) his woman friend. Raras decision to leave Galih, who have becomes her lover and impregnate her, also strengthened by the courage of Raras's bestfriend, a gay who decide to marry his gay counterpart.

Hawa \& Hawa Raras Aku melihat kamu .Kamu lunglai terkapar di kamar yang berantakan serta terikat di tempat tidur.Menyadari diriku mencintaimu seperti pagi mencintai matahari dan kalangan mencintai rembulan.Betapa anehnya, tak ada dari tubuh kita yang mampu mengisi masingmasing lubang di bawah selangkangan (kecuali jari-jari kit a). Tapi aku mengagumimu, indah... apa yang aku punya,kau juga punya. Kitapunya vagina, kita juga punya buah dada.ftu cukuplah bagiku, aku tak akan iri lagi... (Tabularasa, data no. 5).

The two men come out of Deevas and get inside a Charcoal colored car. Before Argus starts his car, the two kisses. Then they step the pedal on to Sutherland area and stops at an apartment. That night the two are exhausted after 
celebrating Zack's promotion at Deevas, a bar that gay people pay visit annually. With what energy left they embraced each other in love. They are in love.

In $\mathrm{Sn}$, it is told that a gay couple, Dhimas and Ruben are involved a project together to write a novel. The relationship between the two which indicates sexual intercourses are not depicted in detail, but are limited as follows.

Kedua pria itu duduk berhadapan.Kehangatan terpancar dari mata mereka. Rasa itumemang masih ada.Masa sepuluh tahun tidak mengaratkan esensi, sekalipun menyusutkan bara. Tidak lagi bergejolak, namun hangat.Hangat yang nampaknya kekal.Bukankah itu yang semua orang cari? (Sn, data no. 1).

The unique thing is, even though the two are officially couple, Ruben and Dhimas, never live under the same roof like other gay couples. If asked, the answer would be -supaya bisa tetap kangen. Tetap dibutuhkan usaha bila ingin bertemu satu sama lain." (Sn, data no. 3)

Next, the sexual intercourse between men (gay) in MM, is done between character Gangga and Prasetyo. Both of that human children are crashed onto a bed covered by purple bed linen. The color of their choices. Those men pass each other smile, smile of satisfaction, smile of pleasure. One of the human child take his counterpart's hand that night.

"Did I make you happy. ..?" "Kamu membahagiakan saya malam ini. Kamu hebat sekali bisa membuat saya berkali-kali orgasme... " "Nama saya Gangga." Gangga menyodorkan tangannya yang satu lagi sibuk mengancingkan kemejanya (MM, data, no. 7).

The character Prasetyo in MM is man who have been engaged by her family to Yukako. In the glasses of Yukako parents, Prasetyo is an ideal man to the husband of Yukako. The same-sex behavior done by Prasetyo and Gangga, who is also a best friend of Yukako, shows that to understand a human, moreover related to private area like sexual tendency is not enough to be seen from outside (seen physical factor and material) only.

Jing tersenyum dan melangkah mendekat ke arah Ken yang masih duduk di atas kasur yang kusut masai. Jing meraih dagu milik Ken.Dagu yang kokoh itu didongakkan padanya dan Jing mencium bibir Ken dengan lembut.Kelembutan dan kedinginan sekaligus merajai sekujur tubuh Ken. Ken merasa ada rasa jijik yang mengasyikkan di dalam ciuman itu (D, data no. 21).

"Ken?" Jing memanggil dan Ken tersadar, dia harus bangun dan menjawab pertanyaan Jing. "Jing, nanti malam... kamu bisa kan pulang ke sini. Aku ingin bersamamu... "Bagus. Kamu sudah menjawab danmemintanya..., "Jing melambai dan segera menutup pintu, meninggalkan Ken di antara keremangan gelap karena gorden jendela tidak dibuka olehnya... (D, data no. 22).

Jing is a man from Tionghoa who came to Indonesia to find and kill his mother. Jing wish to kill his mother because he knows that his existence is rejected by his family because his parent have done incest, Aleda and Magnos, who are siblings by blood. In psychiatry and psychology literature, incest is considered to be a sexual disorder flagged by sensual reaction to couples of who have strong family relationship, like father and daughter, mother and son or between siblings (Sadarjoen, 2006). If homosexual character on Jing is considered an abnormality, then it can be understood to be a form of punishment from a forbidden incest relationship done by his parents. That is the cause of his fury to himself. Jing choices towards Ken, who he understands to be waiting his marriage date, can be also be considered to deliberately destroying heterosexual relationship between Ken and his brides to be. But, when at last ken in his anguish because he is hunted by his brides to be, kills Jing, which means also kill his homosexual desires and Jing's lust to kill his mother, can be interpreted that D is not a novel that supports the idea of homosexual, as well as GTSL and Tr.

The seven novels that have investigated depicts three sexual-intercourse behavior, they are: lesbian behavior in three novels: GTSL, L and N which supports the ideology of radical feminism; Gay behavior in three novels: Sn, MM and $\mathrm{D}$ which supports the idea of being gay that tend to be heterosexual; and mix sexual relationship between lesbian and gay as depicted in novel Tr.

The novels that are support the idea of lesbian (GTSL, L, N) considered as novels that represents the perspective of radical feminism. As it is known that one of manifesto of Radical Feminism published in Notes from the Social Sex (1970) says that marriage institution is formalization institution to oppress women, therefore the primary task of radical feminism is to reject family institution whether in theory or practice. Even radical feminism set a quota to their ranks, that it is hoped not more than one third (1/3) live in marriage institution.

Radical feminism tends to hate men as an individual and ask women to be independent, to the point that the presence of men is un-needed in a woman's life. Elsa Gidow (1977) theorizes that being lesbian is one way to be freed from the dominance of men, internal or external. Martha Shelley (1970) says that lesbians need to be example of independent women. 
"I have never met a Iesbian who was not iz feminist. .. I have never met a Iesbian who believe that she was innately less rational or capable thav a man ... in a male-dominates society, lesbianist is a sign of mental health."

Based theoretical approach and women questions above, it is clear that the focus of radical feminism study related to sex and gender and reproduction problem. It is in accordance with Tong $(1989$, p. 3) claims that every radical feminist focuses on sex, gender and reproduction as the focus to the development of feminist idea.

Some of them have more tendency to androgyny by emphasizing to all kinds of sexual intercourse (heterosexual, lesbian or autoerotic), seeing technology as reproduction helper, and also old technology of reproduction control as an absolute grace to women. On the contrary, other radical feminist reject androgyny, underlining sexual relationship, especially heterosexual, and thinks of reproduction helper technology and most of the old technology of reproduction control as dangerous tool.

Then, Radical Feminism based on a thesis that oppression to women is rooted to the patriarchy ideology as values system and primary authority that rules over relationship between men and women generally, which apparently becomes oppression towards women. The main concern of this belief is the campaign to reject -sexual abuse" women exploitation in sexual way and in pornography. Besides that, this belief also suggests lesbian way of life because with this way women can be freed form men oppression (Dzuhayatin, 1998, p. 16-17). In novel GTSL, it is clearly seen the lesbian's position (Paria and Rie), how they have to fight their family and neighborhood, which represents the dominance of patriarchy. When at last Paria came back to Rie, it is seen that she unruly withstands the dominance of patriarchy, symbolized through the character and power of her father, as can be seen on the following passage:

Kekasihku menanti dan masih menantiku.Sebelum pesawat take-of; meski hanya di dalam hati aku masih sempat mengucapkan sepenggal kalimat untuk laki-laki tua yang mencintaiku dengan tulus kasih seorang bapa.Yang menembang untukku samudra kasihnya untukku.Bapak yang karena cintanya aku memahami makna sesungguhnya dari hidup ini."Dalem wangsul bapak.Pergi ke rumah tempat saya merasakan cinta dan senyuman yang tulus.Nyuwun pangapunten bapak" (GTSL, data No. 19).

Thereby, when Shakuntala in novel L, console Laila who have been cheated by a man (Sihar), also in accordance with radical feminism that suggest the lifestyle of lesbian because this way women can be free from the oppression of men. To understand the existence the lifestyle of lesbianism believed by Shakuntala and becomes solution to Laila's problems who have been disappointed by a man, in the novel can be found the character Shakuntala who consistently fights the practice of patriarchy, as seen in this quotation:

"Nama saya Shakuntala. Orang Jawa tak punya nama keluarga. " "Anda memiliki ayah,bukan?"'Alangkah indahnya kalau tak punya." "Gunakan nama ayahmu," kata wanita di loketitu. "Dan mengapa saya harus memakainya?" "Pormulir harus diisi. "Aku pun marah."Nonya.Anda beragama Kristen bukan?Saya tidak, tapi saya belajar dari seko/ah Katolik.Yesus tidak mempunyai ayah. Kenapa orang harus memakai nama ayah?" Lalu aku tidak jadi memohon visa.Kenapa ayahku harus tetap memiliki sebagian dari diriku? (L, data no 14).

When in relationship with Galih, a woman Raras in Tr have never feel joy sitting the position of subject, but even act as an observer. In detail she watches what Galih have done to her, as seen as follow:

Dapat kurasakan tubuhnya. Wajahnya dekat sekali.Lalu aku dapat merasakan pipi yang menempel di wajah lelah, kelenjar minyak telah memproduksi hasilnya.Debu yang beterbangan pun pasti bercampur di permukaannya, hanya saja tak kasat mata.Aku dapat merasakan bau napasnya dan bau badan keluar dengan khas sendirisendiri.Enzim mulut dan kelenjar keringat bercampur dengan deodoran (Tr, data no.16).

For un-able to feel pleasure in her sexual intercourse with Galih, Raras position becomes Galih's sexual object, that feminism perspective can think of as object from the dominance of patriarchy. Moreover, because having sexual intercourse with Galih, Raras is pregnant. She is tormented and then rejects her own child by doing abortion.

As explain in the findings that the LGBT behavior phenomena found in the modern Indonesia novel that stand out are only two, between women sexual intercourse phenomena and between men intercourse sexual intercourse phenomena. These two sex phenomena, other than can be understood through the perspective of feminism, Phenomena LG (without BT) in some of the novel try to reflect the reality that happen in society, especially the one that relates to the existence of L (BT) in Indonesia. As elaborated by Anderson (in Oetomo, 2003), also Oetomo (2003) says that homosexual reality LG (without BT) in Indonesia have existed since the old times until now. Even in some are in Indonesia like Aceh, Minangkabau, Ponorogo, Madura, Java, the existence of homosexual (LG without BT) was a part that cannot be separated from cultural construction of the people (Oetomo, 2003, p. 1-70)

Next, Oetomo (2003, p. 30) explains that if in the society of Traditional Minangkabau known a relationship between adult man and teenager, the adult man is called indukjawi (literally means Cow's parent) and the teenager is called anak jawi (calf). Based on the information from Oetomo (2003, p. 31) from his respondent, pattern such as this 
present in the surau or between teacher-student in Silat. Such tradition also exist in Ponorogo, East Java in the life of Warok, Sakti person, who have relationship“ with teenager of the same gender, are called Gemblak, which he thought of as replacement of opposite sex partner. The existence of homosexuality in Indonesia cannot be separated from the existence of organization (Paguyuban) that gathers the lesbians and gays in Indonesia. As explains by Oetomo (2003: 46), one of the founders of gay organization, Lambda Nusantara (LI) and now has become a member in the Dewan Pembina Yayasan Gay Nusantara, gay organization founded first on March 11982 by the name Lambda Indonesia (LI) with their bulletin_Gaya Hidup Ceria' (Happy Way of Life), which published 1984. Then, at the start of the year 1985 at Yogyakarata emerged Persaudaraan Gay Yogyakarta (PYG) that have bulletin Jaka, special only for men. In 1988 disbanded and expand their scope to be national and becomes Indonesia Gay Society (GS). November 1987 emerged Kelompok Kerja Lesbian dan Gay Nusantara (KKLGN) that published a book Gay Nusantara. As an organization with certain community member, their existence are supported by the involvement of gay and lesbian in following and doing conference and congress in the scope of National or Transnational, such as Konferensi Regional Asia I LGAII at Tokyo 1920 November 1988, Kongres Lesbian dan Gay Indonesia (KLGI) I (1983), LGI II (1985), KLGI III (1997) (Oetomo, 2003, p. 283). Besides that, the publication of book Memberi Suara pada yang Bisu (2001 reprinted in 2003) by Dede Oetemo, that contains a number of articles and his study results regarding homosexual life (especially LG minus BT) shows phenomena and the existence of LG minus BT people of Indonesia that cannot be seen with one eye closed.

\section{CONCLUSION}

Based on the results of the data analysis and discussion it can be concluded things as follow; First, there are six kinds of sexual intercourse interpreted form the modern Indonesia Novel, they are (1) sexual intercourse between women (lesbian); (2) sexual intercourse between men (gay); (3) Sexual intercourse outside of marriage and prostitution; (4) Affair relationship; (5) sexual intercourse between husband and wife (Normal legal); and (6) Incest. Second, portrait of behavior of LGBT that stand out in the modern Indonesia novels are only three, they are (a) lesbian that is found in novel Garis Tepian Seorang Lesbian, Larung and Nayla (b) gay in novel Supernova, Mahadewa- mahadewi, and novel Dadasime and mix relationship between lesbian and gay in Tabularasa. Third, behavior portrait of sexual intercourse in some of the novel being investigated that relates with reality ideology that alive within society and the ideology of radical feminism. This is in accordance with perspective that says literary works is a copy or portrait of reality that exists within society.

At the end, as overall the phenomena (LG (-BT) in modern Indonesia novel can be differentiated into two entity. First, LB (-BT)as a sickness that someone suffered as an individual that can be caused by medical factor (biological/genetics) and sociological factor or neighborhood. From the perspective of psychology, there are two ways of treatment for LG (-BT), that is hormonal therapy at a hospital for those who experienced cause by hormone. Second, LG (-BT) as a community or organization must have movement or activity (deviates sexual behavior). Therefore, the government of Indonesia and the House of Representatives must arrange legal law to regulate the activity and movement of LGBT, to prevent the spreading of deviation of sexual orientation among the people by doing rehabilitation service and accompanied by assertive and strong law enforcement.

\section{References}

Ayu, D. M. (2005). Nayla. Jakarta: Gramedia Pustaka Utama

Amirudin, M. (2004). Perempuan, Seks dan Teks Sastra yang Bicara," dalam Media Indonesia, 4 Januari.

Anderson, B. (2003). Đari Tjentini Sampai Gaya Nusantara," dalam Dede oetomo, memberi suara pada yang bisu. Yogyakarta: Pustaka Marwa.

Bainar, E. (1998). Wacana perempuan dalam keindonesiaan dan kemodernan. Jakarta: Pustaka Cidesindo bekerja sama dengan Universitas Islam Indonesia dan Yayasan IPPSDM.

Boellstorff, T. (2005). Seksualitas dan bangsa indonesia (terjemahan dari the gay archipelago). London: Princeton University Press

Djajanegara, S. (2000). Kritik sastra feminis: Sebuah Pengantar. Jakarta: Gramedia.

Drescher, J. and Hellman, R. (2004). Handbook of lgbt issues in community mental health. New York: The Haworth Medical Press

Dzuhayatin, S. N. (1998). Hdeologi Pembebasan Perempuan: Perspektif Feminisme dan Islam.” dalam Bainar, Ed. Wacana perempuan dalam keindonesiaan dan kemodernan. Jakarta: Pustaka Cidesindo bekerja sarna dengan Universitas Islam Indonesia dan Yayasan IPPSDM.

Eagleton, T. (2011). Literary theory: An introduction. London: John Wiley \& Sons.

Emka, M. (2004). Jakarta undercover, sex ,n the city. Yogyakarta: Galang Press. Cetakan ke-29.

Goldmann, L., \& Sheridan, A. (1997). Towards a Sociology of the Novel. London: Tavistock Publications.

Hawari. D. (2009). Pendekatan psikoreligi pada homoseksual. Jakarta: Balai Penerbitan FKUI.

Herlinatiens. (2003). Garis tepi seorang lesbian. Yogyakarta:Galang Press. 
Kumala, R. 2004. Tabularasa. Jakarta: Grasindo.

Laurent, E. (2005). Sexuality and human rights: an Asian perspective. Journal of Homosexuality, 48(3-4), 163-225. Lestari, D. (2001). Supernova. Bandung: Trueede Books.

Oetomo, D. (2003). Memberi suara pada yang bisu. Yogyakarta: Pustaka Marwa.

Sartika, D. (2004). Dadaisme. Yogyakarta: Mahatari.

Sadarjoen, S. S. (2006). "Deviasi Seksual, dan Incets hingga Sadisme," Kompas, 22Februari.

Spencer. C. (2011). Sejarah homoseksualitas dari zaman kuno hingga sekarang (terj.) Ninik Rochani Sjams. Bantul: Kreasi Wacana.

Tong, R. P. (1989). Liberal feminism. Radical Feminism.

Utami, A. (2001). Larung. Jakarta: Kepustakaan Populer Gramedia

Yusuf, N. R. (2003). Mahadewa-mahadewi. Jakarta: Sentra Kreasi Inti. 